\title{
The Complex Formation in the Zinc Cyanide and the Cadmium Cyanide Systems
}

\author{
H A N S P RSSON \\ Division of Physical Chemistry, Chemical Center, University of Lund, \\ P.O.B. 740, S.220 07 Lund 7, Sweden
}

\begin{abstract}
The formation of complexes in aqueous solution between cyanide ions and zinc and cadmium ions, respectively, has been studied by potentiometric measurements at $25.0^{\circ} \mathrm{C}$ and ionic strength $3.0 \mathrm{M}$ using sodium perchlorate as ionic medium. The following overall stability constants were obtained (subjectively estimated maximum errors are given).
\end{abstract}

For the zinc cyanide system:

$\beta_{1}=(2.2 \pm 0.5) \times 10^{5} \mathrm{M}^{-1} ; \beta_{2}=(1.06 \pm 0.06) \times 10^{11} \mathrm{M}^{-2}$

$\beta_{3}=(4.8 \pm 0.5) \times 10^{16} \mathrm{M}^{-8} ; \beta_{4}=(3.7 \pm 0.8) \times 10^{21} \mathrm{M}^{-4}$

For the cadmium cyanide system:

$\beta_{1}=(4.2 \pm 0.1) \times 10^{5} \mathrm{M}^{-1} ; \beta_{2}=(6.9 \pm 0.5) \times 10^{10} \mathrm{M}^{-2}$

$\beta_{3}=(5.3 \pm 0.3) \times 10^{16} \mathrm{M}^{-3} ; \beta_{4}=(1.6 \pm 0.4) \times 10^{19} \mathrm{M}^{-4}$

The dissociation constant for hydrogen cyanide, the ionization constant for water, and the stoichiometric solubility product for zinc cyanide were also determined under the specified conditions.

Several investigations of the zinc cyanide and the cadmium cyanide systems

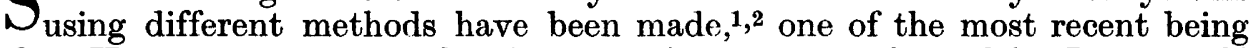
the $\mathrm{pH}$-measurements on the zinc cyanide system performed by Izatt et al. ${ }^{2}$ These authors claim that the species $\mathrm{Zn}(\mathrm{CN})_{2}, \mathrm{Zn}(\mathrm{CN})_{3}{ }^{-}$, and $\mathrm{Zn}(\mathrm{CN})_{4}{ }^{2-}$ exist and give the corresponding stability constants. They also report that no species $\mathrm{ZnCN}^{+}$seems to be formed in the solution. Izatt et al. point out that in most of the work done earlier on the zinc cyanide system, amalgam electrodes have been used, and that zinc amalgam has been reported to be attacked by cyanide ions. Amalgam measurements might thus give doubtful results. However, it seemed odd that the first. complex could not be detected, and it also seemed reasonable that by careful exclusion of oxygen from the solutions and with a low concentration of cyanide ions, the amalgam method might still be successful, at least for determination of the first complexity constant.

Measurements on the zinc cyanide system were therefore performed with both an amalgam electrode and a glass electrode. The cadmium cyanide system, previously studied by Leden ${ }^{8}$ with amalgam electrode measurements, was investigated with the aid of a glass electrode.

Acta Chem. Scand. 25 (1971) No. 2 


\section{CALCULATIONS OF STABILITY CONSTANTS}

The stability constants were determined with the method of graphical integration of $\bar{n} /[\mathrm{A}]$, outlined by Fronæus (Ref. 3, p. 14). The concentration of free ligand $\mathrm{A}$ has been calculated from the equation

$$
[\mathrm{A}]=\frac{K_{\mathrm{a}}\left(C_{\mathrm{H}}+o h-h\right)}{h}
$$

where $K_{\mathrm{a}}$ is the dissociation constant for hydrogen cyanide and $C_{\mathrm{H}}$ the total concentration of perchloric acid in the solution. The concentration of hydrogen ions, $h$, was calculated from measurements with a glass electrode according to the relation

$$
E_{\mathrm{H}}=E_{\mathrm{H}}^{0}-\frac{R T}{F} \ln h
$$

$\bar{n}$ was obtained from

$$
\bar{n}=\left(C_{\mathrm{A}}-[\mathrm{A}]-[\mathrm{HA}]\right) / C_{\mathrm{M}}
$$

An approximate value of $\beta_{1}$ was obtained from a combination of the amalgam measurements and the $\mathrm{pH}$-measurements, the former giving values of the function $X$, and the latter giving the corresponding values of [A].*

\section{EXPERIMENTAL}

\section{Che micals}

Perchloric acid, sodium perchlorate, zinc amalgam, zinc perchlorate, and cadmium perchlorate were as described in a previous paper. ${ }^{4}$ Sodium cyanide was Baker's p.a. sample. It was analysed for cyanide by titration with a silver nitrate solution (Liebig titration). A titration with a standardized solution of perchloric acid showed that the sample contained a small amount of strong base, probably $\mathrm{NaOH}$, that had to be considered in the calculations.

\section{Measurements}

The zinc cyanide system. Combined amalgam-and $p H$-measurements. The measurements on the zinc cyanide system were originally designed in the following way.

A volume $V_{0}$ of a solution $\mathrm{S}_{1}$ was titrated with a solution $\mathrm{T}_{1}$ (with volume $v$ ). $\left(V_{0}=25.00 \mathrm{ml}.\right)$

$$
\mathrm{S}_{1}\left\{\begin{array} { l l } 
{ C _ { \mathrm { M } } } & { \mathrm { Zn } ( \mathrm { ClO } _ { 4 } ) _ { 2 } } \\
{ C _ { \mathrm { HS } } } & { \mathrm { HClO } _ { 4 } } \\
{ 3 \mathrm { M } - 3 C _ { \mathrm { M } } } & { \mathrm { NaClO } _ { 4 } }
\end{array} \quad \mathrm { T } _ { 1 } \left\{\begin{array}{ll}
C_{\mathrm{M}} & \mathrm{Zn}\left(\mathrm{ClO}_{4}\right)_{2} \\
C_{\mathrm{HT}} & \mathrm{HClO}_{4} \\
C_{\mathrm{AT}} & \mathrm{NaCN}_{3 \mathrm{M}-3 C_{\mathrm{M}}-C_{\mathrm{AT}}-C_{\mathrm{HT}}} \\
\mathrm{NaClO}_{4}
\end{array}\right.\right.
$$

Here $C_{\mathrm{M}}, C_{\mathrm{AT}}$, and $C_{\mathrm{HT}}$ had values in the concentration ranges $0.5-1 \mathrm{mM}, 20-100 \mathrm{mM}$, and $10-50 \mathrm{mM}$, respectively. The emf's of the following galvanic cells were measured:
I. $\mathrm{Zn}(\mathrm{Hg})\left|\mathrm{S}_{1}+\mathrm{T}_{1}\right|$
$3.00 \mathrm{M} \mathrm{NaClO}_{4}$
$10 \mathrm{mM} \mathrm{NaCl}$
$\mathrm{Ag}, \mathrm{AgCl}$

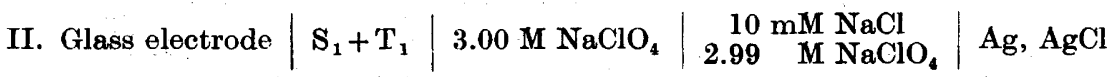

* Symbols, if not else defined, are those used by Fronæus. ${ }^{3}$ 
In this way it was intended to determine both the free central ion concentration and the free ligand ion concentration. However, two difficulties arose in the course of the titrations. Firstly, a precipitation occurred when only a part of a titration series was performed, and secondly, analyses of solutions, before precipitation had occurred, showed that some zinc had been dissolved from the amalgam. The amount of zinc dissolved increased rapidly with the cyanide concentration. The solutions were analysed for zinc both polarographically and by EDTA-titrations. Hence, it was clear that the amalgam method could not be used in the broad range of cyanide concentrations. However, the simultaneous measurements of the free central ion concentration and the free ligand ion concentration gave corresponding values of the function $X_{1}$ and [A] at low ligand concentrations, thus providing an approximate value of $\beta_{1}$. Furthermore, measurements with precipitate present gave an approximate value of the stoichiometric solubility product for $\mathrm{Zn}(\mathrm{CN})_{2}(\mathrm{~s}), K_{\mathrm{s}}=\left[\mathrm{Zn}^{2+}\right]\left[\mathrm{CN}^{-}\right]^{2}$. (The precipitate was analysed and found to be $\mathrm{Zn}(\mathrm{CN})_{2}$ in the ligand range studied.)

The zinc cyanide system. $p H$-measurements. Since the zinc amalgam electrode was proved unsuitable in cyanide-rich solutions, the investigations were continued as pure pH-measurements with a glass electrode. To avoid precipitation the titration series had to be performed with varying $C_{\mathrm{M}}$, by titrating cyanide-rich zinc solutions with perchloric acid. The titration solutions were composed as follows.

$$
\mathrm{S}_{2}\left\{\begin{array} { l l } 
{ C _ { \mathrm { MS } } } & { \mathrm { Zn } ( \mathrm { ClO } _ { 4 } ) _ { 2 } } \\
{ C _ { \mathrm { AS } } } & { \mathrm { NaCN } _ { \mathrm { HS } } ^ { \mathrm { HClO } _ { 4 } } } \\
{ 3 \mathrm { M } - 3 C _ { \mathrm { MS } } - C _ { \mathrm { AS } } } & { \mathrm { NaClO } _ { 4 } }
\end{array} \quad \mathrm { T } _ { 2 } \left\{\begin{array}{l}
C_{\mathrm{HT}} \\
3 \mathrm{M}-C_{\mathrm{HT}}
\end{array} \quad \begin{array}{l}
\mathrm{HClO}_{4} \\
\mathrm{NaClO}_{4}
\end{array}\right.\right.
$$

One series was also performed with constant $C_{\mathrm{M}}$ at such high ligand concentrations that no precipitation could be expected. Even when the titration series were performed in the way outlined above, precipitation occurred for some series in the range about $\bar{n}=2$. The appearance of solid zinc cyanide in a series was immediately shown by a drift in the emf. If no precipitate was formed, the potential attained a stable value within a minute after an addition of titrant solution. To control if this drift really depended upon precipitation, titrant was added until the emf was stable again, i.e. until the precipitate had been dissolved. The values of ([A], $\bar{n}$ ) now calculated were, within the limits of experimental accuracy, the same as those for series where no precipitation had occurred. To avoid precipitation it was essential to use freshly prepared solutions.

The investigations on the cadmium cyanide system were carried out as pH-measurements exactly as described above for the zinc cyanide system. No precipitation of cadmium cyanide was obtained even when $C_{\mathrm{M}}$ was kept constant. In the zinc cyanide measurements the emf was measured with a Radiometer potentiometer pHM 4C and a Beckman glass electrode 40495 . In the studies of the cadmium cyanide system an Orion digital voltmeter was used together with a Jena glass electrode HA 9401/21. The glass electrodes were checked against a hydrogen electrode. The Beckman electrode was found to follow the hydrogen electrode within $0.4 \mathrm{mV}$ and the Jena electrode within $0.2 \mathrm{mV}$ in the range $3<-\log \left[\mathrm{H}_{3} \mathrm{O}^{+}\right]<10.5$. The glass electrodes were calibrated in a buffer [30 mM NaAc, $\left.30 \mathrm{mM} \mathrm{HAc}, 2.97 \mathrm{M} \mathrm{NaClO}{ }_{4}\right]$ in which $-\log \left[\mathrm{H}_{3} \mathrm{O}^{+}\right]=5.015$ according to previous measurements on the proton-acetate system. ${ }^{5}$ The reproducibility of the meas. ured emf in the titration series was in general within $1 \mathrm{mV}$.

Determination of $\mathrm{K}_{\mathrm{w}}$ and $\mathrm{K}_{\mathrm{a}}$. A calculation of the free cyanide ion concentration also requires a value of the ionization constant for water, $K_{\mathrm{w}}$, and the dissociation constant for hydrogen cyanide, $K_{\mathrm{a}}$, in $3 \mathrm{M} \mathrm{NaClO}$ and at $25^{\circ} \mathrm{C}$. $K_{\mathrm{w}}$ was determined from measurements of the hydrogen ion concentration in a solution with known hydroxide ion concentration by means of a hydrogen electrode and $K_{\mathrm{a}}$ from measurements with a glass electrode in a solution $\left(\mathrm{S}+\mathrm{T}_{3}+\mathrm{T}_{4}\right)$ produced by titrating a solution $\mathrm{S}:\left(3.00 \mathrm{M} \mathrm{NaClO}_{4}\right)$ with two solutions, $\mathrm{T}_{3}:\left(C_{\mathrm{A}} \mathrm{NaCN}, 3 \mathrm{M}-\mathrm{C}_{\mathrm{A}} \mathrm{NaClO}_{4}\right)$, and $\mathrm{T}_{4}:\left(C_{\mathrm{H}} \mathrm{HClO}_{4}, 3 \mathrm{M}-C_{\mathrm{H}}\right.$ $\mathrm{NaClO}_{4}$ ).

The following values were obtained from the measurements: $\mathrm{p} K_{\mathrm{w}}=14.184 \pm 0.002$, and $\mathrm{p} K_{\mathrm{a}}=9.484 \pm 0.01$. Agren ${ }^{\circ}$ has reported a value of $\mathrm{p} K_{\mathrm{w}}=14.15 \pm 0.01$, and Ingri et $a l .{ }^{7} \mathrm{p} K_{\mathrm{w}}=14.22 \pm 0.02$.

Acta Chem. Scand. 25 (1971) No. 2 


\section{RESULTS}

The zinc cyanide system. $p H$-measurements. In Tables 1 and 2 some representative values of added volume of titrant and measured emf are collected.

Table 1. Corresponding values of added volume, $v$, of titrant and measured emf, $\boldsymbol{E}_{\mathrm{H}}$, for the zinc cyanide system ( $v$ in $\mathrm{ml}$, und $E_{\mathrm{H}}$ in $\mathrm{mV}$ ).

Series 1

Series 2

\begin{tabular}{|c|c|c|c|c|c|c|c|}
\hline \multicolumn{4}{|c|}{$\begin{array}{c}E_{\mathrm{H}}{ }^{0}=-131.4 \mathrm{mV} \\
C_{\mathrm{MS}}=0.300 \mathrm{mM} ; C_{\mathrm{MT}}=0 \mathrm{mM} \\
C_{\mathrm{AS}}=1.530 \mathrm{mM} ; C_{\mathrm{AT}}=0 \mathrm{mM} \\
C_{\mathrm{HS}}=0.04 \mathrm{mM} ; C_{\mathrm{HT}}=3.030 \mathrm{mM}\end{array}$} & \multicolumn{4}{|c|}{$\begin{array}{c}E_{\mathrm{H}}^{0}=-131.0 \mathrm{mV} \\
C_{\mathrm{MS}}=0.500 \mathrm{mM} ; C_{\mathrm{Mr}}=0 \mathrm{mM} \\
C_{\mathrm{AS}}=3.066 \mathrm{mM} ; C_{\mathrm{AT}}=0 \mathrm{mM} \\
C_{\mathrm{HS}}=0.04 \mathrm{mM} ; C_{\mathrm{HT}}=6.06 \mathrm{mM}\end{array}$} \\
\hline$v$ & $\boldsymbol{E}_{\mathrm{H}}$ & $v$ & $\boldsymbol{E}_{\mathbf{H}}$ & $v$ & $\boldsymbol{E}_{\mathbf{H}}$ & $v$ & $\boldsymbol{E}_{\mathrm{H}}$ \\
\hline & & & & & & & \\
\hline $\begin{array}{l}2.625 \\
2.953\end{array}$ & $\begin{array}{l}372.6 \\
363.9\end{array}$ & $\begin{array}{l}8.050 \\
8858\end{array}$ & $\begin{array}{l}281.0 \\
278.5\end{array}$ & 3.937 & $\begin{array}{l}370.8 \\
3690\end{array}$ & $\begin{array}{l}8.202 \\
8530\end{array}$ & 274.8 \\
\hline 3.281 & 355.0 & $\mathbf{9 . 1 8 6}$ & 275.8 & $\mathbf{4 . 4 6 2}$ & 352.9 & $\mathbf{8 . 8 5 8}$ & 268. \\
\hline 3.609 & $\mathbf{3 4 6 . 4}$ & 9.514 & 272.7 & 4.724 & 344.0 & 9.186 & 265.1 \\
\hline 3.773 & 342.0 & 9.842 & 269.8 & 4.987 & 335.6 & 9.514 & 261.8 \\
\hline 3.937 & 338.2 & 10.170 & 266.7 & 5.118 & 331.4 & 9.842 & 258.8 \\
\hline 4.101 & $\mathbf{3 3 4 . 0}$ & 10.498 & 263.2 & 5.249 & 327.3 & 10.170 & 255.6 \\
\hline 4.265 & 330.6 & 10.826 & 259.1 & 5.380 & 323.4 & 10.498 & 252.1 \\
\hline 4.593 & 324.1 & 11.154 & 254.1 & 5.511 & 319.5 & 10.826 & 248. \\
\hline 4.921 & 318.4 & 11.318 & 250.9 & 5.643 & 315.8 & 10.990 & 246.2 \\
\hline 5.249 & 313.3 & 11.482 & 247.3 & 5.774 & 312.3 & 11.154 & 243.6 \\
\hline 5.577 & 308.7 & 11.646 & 242.5 & 5.905 & 308.1 & 11.318 & 241.1 \\
\hline 5.905 & 304.9 & 11.712 & 240.2 & 6.069 & 305.2 & 11.482 & 238.2 \\
\hline 6.233 & 301.2 & 11.876 & 233.0 & 6.233 & 301.7 & 11.646 & 234.8 \\
\hline 6.561 & 298.0 & 12.007 & 224.5 & 6.397 & 298.4 & 11.745 & 232. \\
\hline 6.889 & 294.9 & 12.138 & 211.2 & 6.561 & 295.6 & 11.941 & 225.8 \\
\hline 7.217 & 291.9 & 12.204 & 202.1 & 6.889 & 290.0 & 12.105 & 217. \\
\hline 7.545 & 290.0 & 12.269 & 191.5 & 7.217 & 285.7 & 12.237 & 206.8 \\
\hline 7.873 & 286.4 & 12.335 & 179.9 & 7.545 & 281.8 & 12.335 & 194.8 \\
\hline 8.202 & 283.7 & 12.401 & 169.3 & 7.873 & 278.1 & 12.466 & 168.2 \\
\hline
\end{tabular}

In order to get a realistic conception of the error limits, the calculations were performed in the following way. $\bar{n} /[\mathrm{A}]$ was plotted as a function of [A] for the different series, and one upper and one lower limiting curve were then drawn. No variation of $\bar{n} /[\mathrm{A}]$ with $C_{\mathrm{M}}$ could be detected. By graphical integrations and plots of successive $X_{i}$-functions ${ }^{3}$ the corresponding two sets of stability constants were determined.

The following average values were obtained:

$$
\begin{array}{ll}
\beta_{1}=(2.2 \pm 0.5) \times 10^{5} \mathrm{M}^{-1} ; & \beta_{2}=(1.06 \pm 0.06) \times 10^{11} \mathrm{M}^{-2} \\
\beta_{3}=(4.8 \pm 0.5) \times 10^{16} \mathrm{M}^{-3} ; & \beta_{4}=(3.7 \pm 0.8) \times 10^{21} \mathrm{M}^{-4}
\end{array}
$$

The complex formation curve, $\bar{n}([\mathrm{~A}])$, calculated from the stability constants, is drawn in Fig. 1 , and in the same diagram some experimental values are plotted. 
Table 2..Corresponding values of added volume, $v$, of titrant and measured emf, $E_{\mathrm{H}}$, for the zinc cyanide system. The second titration series was performed with constant $C_{\mathrm{M}}=1.017 \mathrm{mM}$ and without ligand in the titrant $\left(v\right.$ in $\mathrm{ml}$, and $E_{\mathrm{H}}$ in $\left.\mathrm{mV}\right)$.

Series 3

Series 4

\begin{tabular}{|c|c|c|c|c|c|c|c|}
\hline \multirow[b]{2}{*}{$v$} & \multicolumn{4}{|c|}{$\begin{array}{c}E_{\mathrm{H}}^{0}=-127.4 \mathrm{mV} \\
C_{\mathrm{MS}}=0.304 \mathrm{mM} ; C_{\mathrm{MT}}=0 \mathrm{mM} \\
C_{\mathrm{AS}}=1.238 \mathrm{mM} ; \quad C_{\mathrm{AT}}=0 \mathrm{mM} \\
C_{\mathrm{HS}}=0.02 \mathrm{mM} ; \quad C_{\mathrm{HT}}=2.518 \mathrm{mM}\end{array}$} & \multirow[b]{2}{*}{$E_{\mathbf{H}}$} & \multicolumn{2}{|c|}{$\begin{array}{l}E_{\mathrm{H}}^{0}=-119.2 \mathrm{mV} \\
C_{\mathrm{AS}}=10.03 \mathrm{mM} \\
C_{\mathrm{HS}}=0.01 \mathrm{mM} \\
C_{\mathrm{HT}}=20.21 \mathrm{mM}\end{array}$} \\
\hline & $E_{\mathbf{H}}$ & $v$ & $E_{\mathrm{H}}$ & $v$ & & $v$ & $\boldsymbol{E}_{\mathbf{H}}$ \\
\hline 1.936 & 363.2 & 5.643 & 308.0 & 10.728 & 265.2 & 6.102 & 340.5 \\
\hline 2.132 & 358.6 & 6.036 & 304.6 & 11.056 & 260.1 & 6.168 & 336.3 \\
\hline 2.329 & 354.0 & 6.430 & 301.3 & 11.285 & 255.8 & 6.233 & 332.3 \\
\hline 2.526 & 349.7 & 6.824 & 298.3 & 11.482 & 251.8 & 6.299 & 328.3 \\
\hline 2.756 & 345.1 & 7.217 & 295.4 & 11.646 & 247.0 & 6.397 & 322.6 \\
\hline 2.985 & 340.8 & 7.545 & 292.7 & 11.810 & 240.0 & 6.496 & 317.3 \\
\hline 3.248 & 336.0 & 7.873 & 290.5 & 11.876 & 236.3 & 6.594 & 312.1 \\
\hline 3.543 & 331.3 & 8.202 & 288.0 & 11.941 & 231.8 & 6.692 & 307.3 \\
\hline 3.871 & 326.8 & 8.694 & 284.4 & 11.991 & 227.7 & 6.791 & 302.5 \\
\hline 4.199 & 322.7 & 9.186 & 280.6 & & & 6.889 & 298.1 \\
\hline 4.560 & 318.5 & $\mathbf{9 . 6 7 8}$ & 276.7 & & & 6.988 & 293.4 \\
\hline 4.921 & 314.8 & 10.071 & 272.6 & & & 7.086 & 290.0 \\
\hline 5.249 & 311.5 & 10.400 & 269.2 & & & 7.185 & 284.8 \\
\hline
\end{tabular}

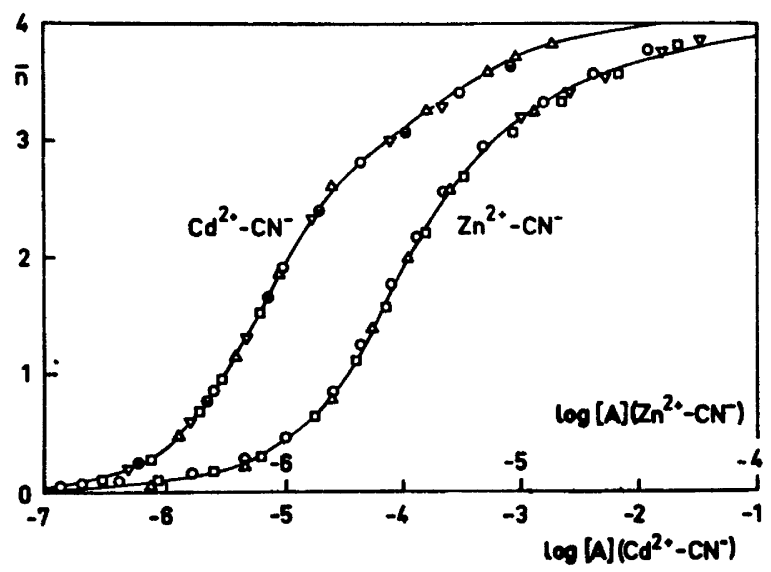

Fig. 1. The complex formation curves for the zinc and cadmium cyanide systems. The full-drawn curves represent $\bar{n}$ calculated from the stability constants. $\bar{n}$ calculated from eqn. (3) is denoted by $O$ (series 1), $\square$ (series 2), $\Delta$ (series 3), and $\nabla$ (series 4) for the zinc system; and by $O$ (series 5), $\square$ (series 6), $\Delta$ (series 7), $\nabla$ (series 8), and $\ominus$ (series 9) for the cadmium system. ([A] in M.)

The zinc cyanide system. Combined amalgam-and $p H$-measurements. From the combined measurements of central ion and ligand concentrations apActa Chem. Scand. 25 (1971) No. 2 
proximative values of $\beta_{1}=(3 \pm 1.5) \times 10^{5} \mathrm{M}^{-1}$ and $K_{\mathrm{s}}=(3.3 \pm 1.3) \times 10^{-16} \mathrm{M}^{-3}$ were obtained.

The cadmium cyanide system. The stability constants for the cadmium cyanide system were calculated by analogy to the zinc cyanide system. The

Table 3. Corresponding values of added volume, $v$, of titrant and measured emf, $E_{\mathrm{H}}$, for the cadmium cyanide system ( $v$ in $\mathrm{ml}$, and $E_{\mathbf{H}}$ in $\mathrm{mV}$ ).

Series 5

Series 6

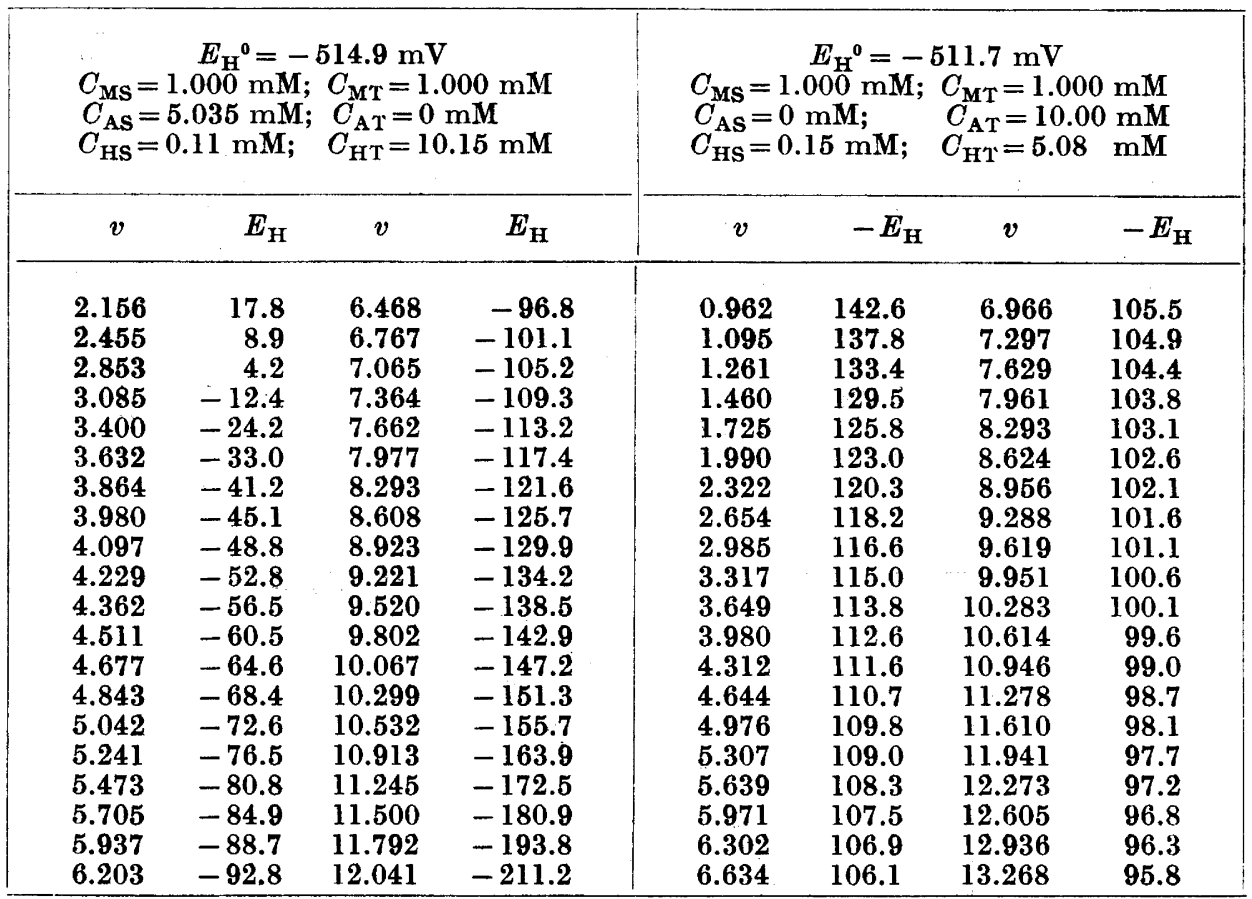

experimental results are collected in Tables 3 and 4 . The following values were obtained from the calculations:

$$
\begin{array}{ll}
\beta_{1}=(4.2 \pm 0.1) \times 10^{5} \mathrm{M}^{-1} ; & \beta_{2}=(6.9 \pm 0.5) \times 10^{10} \mathrm{M}^{-2} \\
\beta_{3}=(5.3 \pm 0.3) \times 10^{15} \mathrm{M}^{-3} ; & \beta_{4}=(1.6 \pm 0.4) \times 10^{19} \mathrm{M}^{-4}
\end{array}
$$

The complex formation curve is drawn in Fig. 1.

\section{DISCUSSION}

The potentiometric measurements on the zinc cyanide and the cadmium cyanide systems can be explained by assuming that four mononuclear complexes are formed in both systems. The measurements on the zinc cyanide system were rendered difficult by the low solubility of zinc cyanide. The 
Table 4. Corresponding values of added volume, $v$, of titrant and measured emf, $E_{\mathrm{H}}$, for the cadmium cyanide system ( $v$ in $\mathrm{ml}$, and $E_{\mathrm{H}}$ in $\mathrm{mV}$ ).

Series 7

Series 8

\begin{tabular}{|c|c|c|c|c|c|c|c|}
\hline \multicolumn{4}{|c|}{$\begin{array}{c}E_{\mathrm{H}}{ }^{0}=-511.3 \mathrm{mV} \\
C_{\mathrm{MS}}=1.000 \mathrm{mM} ; C_{\mathrm{MT}}=1.000 \mathrm{mM} \\
C_{\mathrm{AS}}=25.00 \mathrm{mM} ; C_{\mathrm{AT}}=0 \mathrm{mM} \\
C_{\mathrm{HS}}=0.00 \mathrm{mM} ; \quad C_{\mathrm{HT}}=50.15 \mathrm{mM}\end{array}$} & \multicolumn{4}{|c|}{$\begin{aligned} & E_{\mathrm{H}}^{0}=-514.3 \mathrm{mV}-C_{\mathrm{MT}}=2.000 \mathrm{mM} \\
& C_{\mathrm{MS}}=2.000 \mathrm{mM} ; C_{\mathrm{HT}}=0 \mathrm{mM} \\
& C_{\mathrm{AS}}=10.07 \mathrm{mM} ; C_{\mathrm{HS}}=0.23 \mathrm{mM} ; \quad C_{\mathrm{HT}}=20.29 \mathrm{mM}\end{aligned}$} \\
\hline$v$ & $-E_{\mathrm{H}}$ & $v$ & $-E_{\mathrm{H}}$ & $v$ & $-E_{\mathrm{H}}$ & $v$ & $-E_{\mathrm{H}}$ \\
\hline 8.624 & -0.3 & 10.979 & 136.7 & 1.493 & -31.5 & 6.833 & 118.4 \\
\hline 8.956 & 8.4 & 11.112 & 142.6 & 1.824 & -21.0 & 7.098 & 122.4 \\
\hline 9.122 & 13.8 & 11.278 & 149.9 & 2.156 & -10.1 & 7.364 & 125.6 \\
\hline 9.288 & 19.7 & 11.444 & 157.0 & 2.620 & 6.3 & 7.629 & 129.6 \\
\hline 9.453 & 26.8 & 11.610 & 164.5 & 2.902 & 16.7 & 7.911 & 132.9 \\
\hline 9.619 & 35.1 & 11.775 & 172.7 & 3.218 & 30.0 & 8.193 & 137.0 \\
\hline 9.785 & 44.9 & 11.941 & 182.0 & 3.483 & 41.0 & 8.492 & 140.6 \\
\hline 9.851 & 49.7 & 12.107 & 193.7 & 3.781 & 53.4 & 8.790 & 145.1 \\
\hline 9.918 & 54.6 & 12.273 & 209.9 & 3.980 & 60.7 & 9.089 & 148.8 \\
\hline 9.984 & 60.1 & 12.439 & 241.0 & 4.213 & 68.3 & 9.371 & 152.7 \\
\hline 10.051 & 65.9 & 12.605 & 283.0 & $\mathbf{4 . 4 7 8}$ & 75.9 & 9.653 & 157.1 \\
\hline 10.117 & 72.4 & & & 4.810 & 84.1 & 9.885 & 161.3 \\
\hline 10.183 & 79.3 & & & 4.976 & 87.3 & 10.117 & 164.7 \\
\hline 10.283 & 89.6 & & & 5.175 & 91.9 & 10.349 & 169.4 \\
\hline 10.382 & 99.0 & & & 5.374 & 95.3 & 10.747 & 177.6 \\
\hline 10.482 & 107.5 & & & 5.573 & 99.4 & 11.112 & 186.6 \\
\hline 10.581 & 114.7 & & & 5.805 & 102.9 & 11.361 & 194.2 \\
\hline 10.681 & 121.0 & & & 6.054 & 107.3 & 11.576 & 202.3 \\
\hline 10.780 & 126.6 & & & 6.302 & 110.8 & 11.792 & 211.9 \\
\hline 10.880 & 131.9 & & & 6.568 & 115.1 & 12.008 & 227.5 \\
\hline
\end{tabular}

\begin{tabular}{|c|c|c|c|c|c|c|c|}
\hline \multirow[b]{2}{*}{$v$} & \multicolumn{2}{|c|}{$\begin{array}{l}\text { Series } 9 \\
C_{\mathrm{MS}}=5.00 \mathrm{mM} ; \\
C_{\mathrm{M}^{\top} \mathrm{T}}=5.00 \mathrm{mM}\end{array}$} & \multicolumn{5}{|c|}{$\begin{aligned} E_{\mathrm{H}}^{0} & =-512.9 \mathrm{mV} \\
\mathrm{M} ; \quad C_{\mathrm{HS}} & =0.57 \mathrm{mM} \\
C_{\mathrm{HT}} & =50.72 \mathrm{mM}\end{aligned}$} \\
\hline & $-E_{\mathrm{H}}$ & $v$ & $-E_{\mathrm{H}}$ & $v$ & $-E_{\mathrm{H}}$ & $v$ & $-E_{\mathbf{H}}$ \\
\hline 2.023 & -5.0 & 3.715 & 69.5 & 6.103 & 123.3 & 8.923 & 168.9 \\
\hline 2.222 & 3.3 & 3.881 & 76.3 & 6.369 & 133.3 & 9.205 & 172.9 \\
\hline 2.388 & 10.1 & 4.047 & 82.5 & 6.634 & 137.3 & $\mathbf{9 . 4 8 7}$ & 177.2 \\
\hline 2.554 & 17.2 & 4.279 & 90.3 & 6.899 & $\mathbf{1 4 1 . 2}$ & 10.001 & 185.6 \\
\hline 2.720 & 24.2 & 4.578 & 98.9 & 7.165 & 144.9 & 10.432 & 193.5 \\
\hline 2.886 & 31.5 & 4.859 & 105.9 & 7.447 & 148.7 & 10.797 & 201.5 \\
\hline 3.052 & 39.0 & 5.208 & 113.3 & 7.745 & 152.7 & 11.095 & 209.1 \\
\hline 3.218 & 46.7 & 5.407 & 117.2 & 8.044 & 156.8 & 11.444 & 220.6 \\
\hline 3.383 & 54.5 & 5.622 & 121.2 & 8.342 & 160.8 & 11.891 & 244.6 \\
\hline $\begin{array}{l}3.549 \\
3\end{array}$ & 62.2 & 5.855 & 125.2 & 8.641 & 164.9 & 12.024 & 256.6 \\
\hline
\end{tabular}

investigations indicate that a species $\left[\mathrm{ZnCN}^{+}\right]$exists, in contrast to the reports of Izatt et al. ${ }^{2}$ The fact that these authors have not detected the first complex, Acta Chem. Scand. 25 (1971) No. 2 
may be explained by its rather narrow range of existence. Titrations of alkaline zinc cyanide solutions with perchloric acid result in an increased uncertainty in $\bar{n}$ at the end of the titrations, where the first complex should be determined.

In keeping $C_{\mathrm{M}}, C_{\mathrm{A}}$, and $C_{\mathrm{H}}$ of about the same magnitude and with the use of a very accurate burette, this uncertainty has been decreased in the present investigations. In addition, the combined amalgam- and $\mathrm{pH}$-measurements give about the same value of $\beta_{1}$ as do the $\mathrm{pH}$-measurements. In view of the large difference in ionic strength, the values of $\beta_{2}, \beta_{3}$, and $\beta_{4}$ obtained in the present work in $3 \mathrm{M} \mathrm{NaClO}_{4}$ agree surprisingly well with those reported by Izatt et al. at zero ionic strength. The measurements on the cadmium cyanide system were not hampered by any precipitation, and a wider range of metal ion concentration could be used. The magnitudes of the stability constants in this investigation, especially of $\beta_{1}$ and $\beta_{2}$, are about the same as those determined by Leden ${ }^{8}$ with the use of amalgam electrodes.

In previous investigations of the thiosulfate and acetate systems of zinc and cadmium, $, 4,5$ the cadmium complexes have been found to be considerably stronger than the zinc complexes. For the cyanide systems, this trend is valid only for the first complex, but is reversed for the following ones.

Acknowledgements. I express my gratitude to my teacher, Professor Ido Leden, for his kind interest in this work and for valuable advice, to Dr. Ingmar Grenthe for valuable discussions, and to Dr. Peter Sellers for correcting the English of this manuscript.

\section{REFERENCES}

1. Sillén, L. G. and Martell, A. E. Stability Constants of Metal Ion Complexes, The Chemical Society, London 1964.

2. Izatt, R. M., Christensen, J. J., Hansen, J. W. and Watt, G. D. Inorg. Chem. 4 (1965) 718.

3. Fronæus, S. Komplexsystem hos koppar, (Diss.), University, Lund 1948.

4. Persson, H. Acta Chem. Scand. 24 (1970) 3739.

5. Persson, H. Acta Chem. Scand. 25 (1971) In press.

6. Agren, A. Acta Chem. Scand. 9 (1955) 49.

7. Ingri, N., Lagerström, G., Frydman, M. and Sillén, L. G. Acta Chem. Scand. 11 (1957) 1034.

8. Leden, I. Potentiometrisk undersökning av några kadmiumsalters komplexitet, (Diss.), Lund 1943; Svensk Kem. Tidskr. 56 (1944) 31.

Received June 17, 1970. 